\title{
The symmetry of khayamiya and quilting: International relations of the Egyptian tentmakers
}

\author{
Sam Bowker
}

\begin{abstract}
The tentmakers of Cairo or khayamin (derived from the Arabic word for tent, khayam), can demonstrate ongoing engagement with changes in the usage, composition and production of their traditional craft: khayamiya (Egyptian tentmaker appliqué). These changes have resulted in new patronage from quilters, moving khayamiya from a locally marginalised folk product to global recognition as a spectacular Egyptian craft. This collaboration highlights the long-term engagement of nonEgyptian audiences by the tentmakers, who have responded to changing local conditions and attitudes by directing their work to the interests of foreign collectors, rather than the local Egyptian market. In turn, this has prompted new evaluations of their largely unexplored history. ${ }^{1}$
\end{abstract}

By reviewing these changes, it will be shown that contemporary khayamiya serve longstanding cultural imperatives that are both Egyptian and nonEgyptian. For over a century the tentmakers have engaged with orientalist imaginations without losing their cultural foundations. Their collaboration with quilters presents a logical continuation of their adaptability to exigencies that has enabled them to sustain their distinctive and diverse craft. In turn, this mutual engagement has resulted in the deeper contextualisation and reappraisal of khayamiya as contemporary craft.

\section{Introduction}

It is an archetype, verging on cliché, to present a case study of an exotic nonWestern craft, threatened with extinction by an array of modern and global developments in commerce, politics, society, and design, that has been 'rescued' by integration into an established craft paradigm for a Western bourgeois audience. Regardless of their veracity, such narratives influence both popular and academic interpretations of such 'exotic and endangered' crafts. Such perceptions may

\footnotetext{
1 I was first introduced to khayamiya by my mother, quiltmaker Jenny Bowker, whose close friendships with the tentmakers of Cairo prompted her voluntary work as a spokesperson for this largely unrecognised textile art form. After a chance encounter with Matisse's Interior with Egyptian Curtain (1948), I realised that the origins and art historical implications of khayamiya had not yet been explored. My current research addresses this gap.
} 
misrepresent craftspeople, who have created their own market by actively serving such paradigms in a manner that has evolved over generations. This is the case for khayamiya, also known as Egyptian tentmaker appliqué. ${ }^{2}$

In a previous issue of this journal, Kevin Murray called for a 'symmetry of opportunity' to be established between all parties involved in international cultural and material craft collaborations (2010). This paper considers if symmetry has been achieved in the collaboration between tentmakers (as designers and producers) and quilters (as collectors and curators) by assessing the interaction of these crafts, their historical resemblance, and their situation in the present regarding institutional recognition and social esteem.

Exhibitions of khayamiya in quilt contexts, and the presence of tentmakers during such exhibitions to demonstrate the craft and discuss their work, acknowledge the postcolonial demand to hear the voices of the makers of cultural goods. This also reinforces and retains the 'ethnicity' as well as the authenticity of khayamiya, which is described by curators in terms of being historically and culturally 'Egyptian'. The juxtaposition of khayamiya in quilting exhibitions also reveals the relationship between Western and 'other' craft heritages, situating both disciplines in a broader framework to the benefit of all parties.

While retaining the capacity to change in response to new commercial and cultural imperatives, the design integrity of khayamiya provides a substantial part of their value to non-Egyptian audiences and curators. It has also led to a re-evaluation of the historic interaction between tentmakers, their craft and nonEgyptian audiences. This has already resulted in a 'symmetrical' reassessment of khayamiya's cultural roles for both the tentmakers and Western audiences. These developments can be directly attributed to the engagement of the international (especially American, European and Australian) quilting community with the tentmakers, due to their support of khayamiya as an 'exotic and imperilled' craft with many parallels to their own.

2 'Khayamiyya' is arguably a more accurate transliteration from the original Arabic, but the 'yy' is alien to English-speaking audiences. 


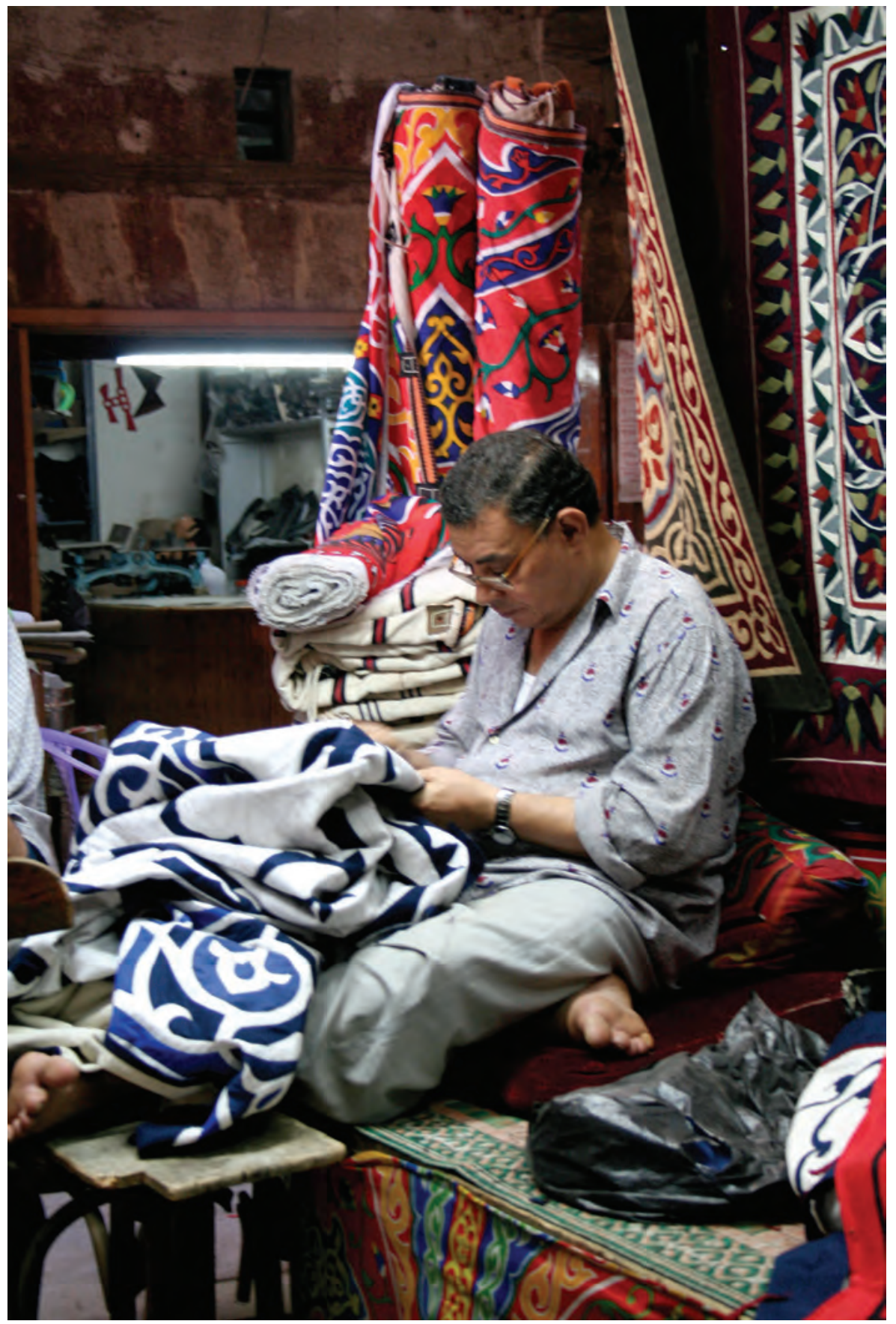

Figure 1. An Egyptian tentmaker (khayami) working on the Street of the Tentmakers, Cairo, 2006 


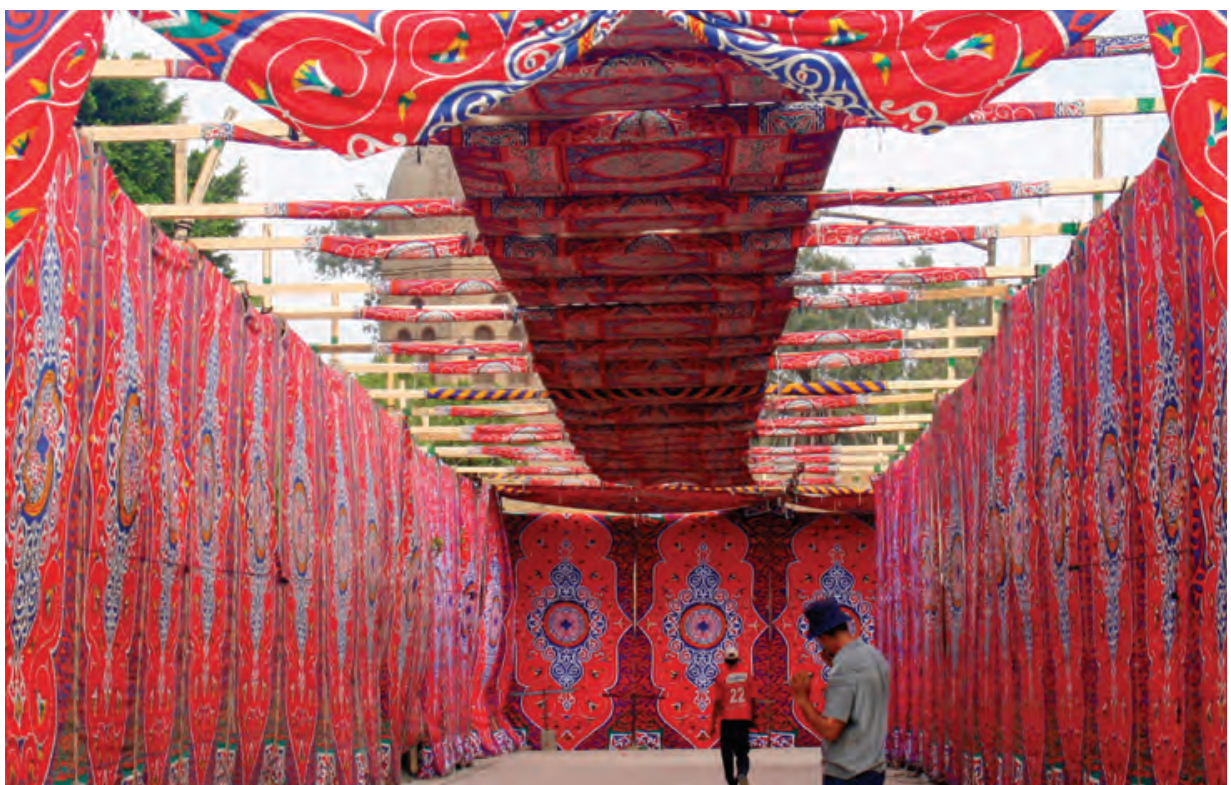

Figure 2. Khayamiya in local context, prior to an event in the City of the Dead, Cairo, 2007

Photo: Jenny Bowker

\section{Khayamiya: Technique and context}

Khayamiya is a spectacular aspect of the living craft heritage of Egypt. It is traditionally hand-stitched by skilled men (khayamin or tentmakers) along the Sharia Khayamiya near Bab Zuweila in Cairo. ${ }^{3}$ They sit cross legged with their backs supported against a wall to appliqué small patches of coloured cotton across a canvas backing, which is discretely marked out with a carefully ponced design for guidance. The process is handwork, using a needle, thimble, and large pair of tailor's scissors. Cotton pieces are cut loosely and folded with precision to be sewn into specific shapes. The work is laborious, sophisticated, and surprisingly fast. Basic sewing machines are only used to join large panels together when constructing giant street tents or suradeq.

Contemporary khayamiya use soft commercial cottons and Egyptian-made threads in a vast array of colours (colour selection is an important consideration in khayamiya design), but historically the tentmakers used cottons tinted with

3 This is the 'Street of the Tentmakers', also known as the Khan el-Khayamiya or Tentmaker's Market. To be more accurate in architectural terms, this covered street is the Qasaba of Radwan Bey. It consists of parallel rows of small shops occupying the ground level of a pair of two-storey buildings. These buildings are linked by a bridge-like ceiling that shades the entire street from Cairo's sun and persistent dust. Such covered streets were once typical in Cairo, but this is a nowrare example. 
vegetable dyes, as these were most accessible in Egypt prior to the 1920s, as well as recycled scraps of clothing. In these respects, the historical techniques of quilting and khayamiya are remarkably similar. Contemporary khayamiya meet the 'quilt' definition of 'three layers held together by thread' because there are usually two layers under the appliqué (a heavier canvas and a soft face) but Khedival (1867-1914) khayamiya consist of appliqué over a canvas backing.

Handmade khayamiya originally took the form of large and elaborate tents or pavilions, like the magnificent 'travelling palaces' of the Ottoman Empire. Such decorative textiles still perform conspicuous roles in Egyptian public and private life, as they are hired as backdrops and venues for weddings, funerals, feasts and many other celebrations. Handmade khayamiya, however, has been largely replaced by mass-printed panels of fabric or 'imitation khayamiya'. These printed fabric panels are appealing to consumers because they are cheaper, lighter, and easier to display than handcrafted versions. Though imitation khayamiya has made this textile art form more 'accessible', it has also undermined the ability of the tentmakers to sustain their skilled profession.

\section{Publishing khayamiya: A brief literature overview}

In historic terms, the tentmakers have largely avoided academic scrutiny. The earliest English-language commentaries on the khayamiya were written by Douglas Sladen in 1908 and 1911. Sladen's opinions are a rare record of European attitudes to khayamiya in the early twentieth century, coinciding with the transition in style from Khedival to the touristic. He makes several distinctions, based on his personal taste, between good and bad tentmaker work, differentiated by subject matter rather than craftsmanship. He admires the older specimens of Khedival khayamiya that once hung in mosques and older Egyptian homes, and acknowledges the cultural and celebratory roles played by khayamiya for Egyptians, which have remained more-or-less consistent to this day. ${ }^{4}$

Sladen's aggressively opinionated account dismisses the departure from Khedival forms towards the touristic as a degradation of the art form, describing the tentmakers as 'vulgar imitators' of the ancient tomb painters. His Eurocentric perspective is exaggerated by his suggestion to the reader that a 'far better result' would follow from copying the work of English cartoonist Lance Thackeray, specifically the Light Side of Egypt, a satirical overview of tourists and their Egyptian associates (Sladen 1911b: 239-40). ${ }^{5}$

4 He describes their local use 'in enormous quantities for decorating the insides of the canvas pavilions, which they erect on any provocation, sometimes in the street for a wedding, or the return of a pilgrim from Mecca; sometimes in a regular encampment for an occasion like the birthday of the Prophet; and which they use a great deal in mosques' (Sladen 1911a: 143-44).

5 Examples of Lance Thackeray's cartoon work can be seen here: http://www.maryevans.com/ lb.php?ref=16801. 
The tentmakers are the most hopelessly vulgarised of all the denizens of the bazaar; elsewhere I have inveighed against them for prostituting their art by substituting coarse caricatures of the ancient Egyptian tomb paintings for the beautiful texts and arabesques which are on the awnings and tent linings they make for Arabs. (Sladen 1911a: 72-73)

Another account of the early touristic khayamiya was recorded by Mary Roberts Rinehart in Nomad's Land (1926), which was also cited by Blaire Gagnon in 2003. Rinehart describes the 'pharaonic' appliquéd decoration of her expedition tent in highly favorable terms, 'no ordinary tent this, but one of the finest specimens of the tent-maker's art ... in strong and primitive colours, a gorgeous thing' (Rinehart 1926: 32).

In contrast to Sladen's account, which does not appear to have been known to subsequent researchers, other studies have presented a sympathetic perspective on the pressures that have driven adaptations within the khayamiya. John Feeney's illustrated 1986 article for Saudi Aramco World outlined the historic and present-day situation of the tentmakers in terms of their local consumption and cultural context as an increasingly marginalised craft profession. Likewise, Caroline Stone's 2010 article for the same journal ('Movable palaces') examines the material and social history of the decorated tent in the Middle East, drawing on research into the Ottoman period by Nurhan Atasoy (2000), thus expanding on Feeney's documentation.

Denise Ammoun's text discusses the work of the tentmakers within the context of other living Egyptian crafts (1991: 51-57). More recently, Robert Bowker (the author's father) provided an overview of the socio-economic situation of the tentmakers, which considers their marginalisation from aspects of the Egyptian tourism sector and lack of government intervention on their behalf (2010: 153-55). John Gillow's survey of Islamic textiles includes reference and illustrations for both Khedival and touristic forms of khayamiya, which is unusual in published accounts so far (2013: 91-93). Heba Barakat's Beyond Boundaries catalogue features the most thorough analysis currently dedicated to a single khayamiya specimen, the 'Egyptian Wedding Tent' in the collection of the Museum of Islamic Art in Kuala Lumpur, Malaysia (2003). Peter Alford Andrews has published the most extensive scholarship on the tents of the Middle East through his Felt Tents and Pavilions: The Nomadic Tradition and its Interaction with Princely Heritage (1997) and Nomad Tent Types in the Middle East (1999). Neither Barakat nor Andrews examine touristic khayamiya in depth, presumably because, for the most part, touristic khayamiya are not actually 'tents'. ${ }^{6}$

Published Arabic references to khayamiya are rare and challenging to access, though perhaps the most accessible is Ashraf Abdul-Yazid's 2003 article for A/-

6 Rare examples of complete tents in the touristic form exist in private collections, including those of Randy Pace (c. 1910-1920s) and Jeanette Martin (c. 1950-1960s). Sladen also described their use as walls for a restaurant in the Karun Hotel in Fayoum (Sladen 1911a: 239-40), the exterior of which has been recorded in postcards, as well as Rinehart's 1926 account. Khedival forms are more frequently encountered as complete tents today. 
Arabi. This text is most noteworthy for Abdul-Yazid's reference to the research of Ismat Ahmad Awad, who collected tentmaker terminology for specific aspects of their design. These Arabic terms demonstrate articulations of this craft that are yet to be presented to an English-language audience, and provide yet another corollary with quilting, which has a descriptive design lexicon of its own. Popular articles, such as those seen in Egyptian news media (Al-Sayyed 2012; Ramadan 2010; Aly Shawky 2011) and the New York Times (Sachs 2000) or Sydney Morning Herald (Wroe 2008), are also useful to gauge increasing public interest and glimpse chronological changes in the Street of the Tentmakers. It is noteworthy that all of these articles make reference to a primary concern of the tentmakers being engagement with non-Egyptians via tourism, rather than local consumption of khayamiya.

\section{Primary references to khayamiya beyond Egypt}

References to khayamiya, especially the touristic form, can be seen in Englishlanguage craft and interior design publications throughout the twentieth century, although this term was not used until 1986. They were praised in newspapers as versatile and charming objects ('Egyptian tent work' 1926). Applications of khayamiya to 'brighten up dark corners' ('Egyptian cloth' 1930) or within a 'peasant colour scheme' ('Martha' 1939), or to decorate fancy-dress balls ('The Lord Mayor's Ball' 1926; 'Near and far' 1923; 'La Donna' 1954), ${ }^{7}$ demonstrate the availability and popularity of touristic khayamiya beyond Egypt. Egyptian tentmaker work appears to have been especially popular in Australia in the 1930s, given that it appears in announcements from Sydney to Albany, Tasmania to Townsville ('Very special auction of high class furnishings' 1932). Some advertisements claimed that Australian retailers received them from London-based exporters, indicating that the trade in touristic Egyptian crafts historically benefitted non-Egyptian retailers (Advertisement 1929). Prices by size were listed in newspaper advertisements, demonstrating that these were relatively accessible decorative objects, even when exported beyond Egypt (Myer Emporium 1930/1931).

Newspaper records also show the recurrence of khayamiya in Australian quilt and textile craft events, including Brisbane ('Australian exhibition of women's work' 1907) and Hobart ('Egyptian cloth' 1944), though they were not exhibited as a distinct genre of textile craft until $2007 .{ }^{8}$ Touristic forms were featured and illustrated as 'typical' of tentmaker appliqué by Sheila Paine (1990: 99) and Mary Gostelow (1982: 201) in their accounts of global embroidered crafts, both written for craft practitioners and researchers. These are similar in several respects to Octavia B. Simpson's 1928 article for The Embroideress, which was cited by Blaire Gagnon as an early study of tentmaker appliqué in a Western

7 In 'The Lord Mayor's Ball', khayamiya use is illustrated in a black and white image.

8 This exhibition was the first Stitch like an Egyptian in the Melbourne Quilt Convention, curated by Jenny Bowker with tentmaker representation by Ahmed Naguib and Ayman Ahmed. 
craft context. Earlier still is an anonymous Every Woman's Encyclopedia article (1910-1912) that describes and illustrates 'Egyptian patch-work' as durable, decorative and inspirational for amateur projects.

The use of complete 'Egyptian tents' is recorded in Australia at public and private events ranging from festivals, social charity events, and weddings around the Federation era. ${ }^{9}$ Given the rarity of these complete tents and their chronological proximity, it is possible that some of those sources are referring to the same tent in different contexts. Their sparse descriptions may encompass both touristic and Khedival forms of khayamiya.

\section{Collecting khayamiya: The role of 'touristic khayamiya' beyond Egypt}

Interest from Western quilters does not reflect the recognition of khayamiya in museums and art galleries. Khayamiya is under-represented in collections of Egyptian material heritage. Unless collected by museums of Islamic art or wealthy textile connoisseurs, khayamiya were generally exposed to the dry and dusty open air of Egypt for extended periods. Since most specimens were enormous pavilions or suradeq, relatively few historic examples have survived. Moreover, these older specimens are seen as 'folk art' (at best) and are not consistently valued by Egyptian audiences, such that khayamiya are rarely represented in Egyptian museum collections today.

9 References to khayamiya (Egyptian tents) in Australian newspapers from 1897 ('Easter fair', 1899 ('Matrimonial'), 1900 ('The Sydney City Mission') and 1917 ('Social world'). 

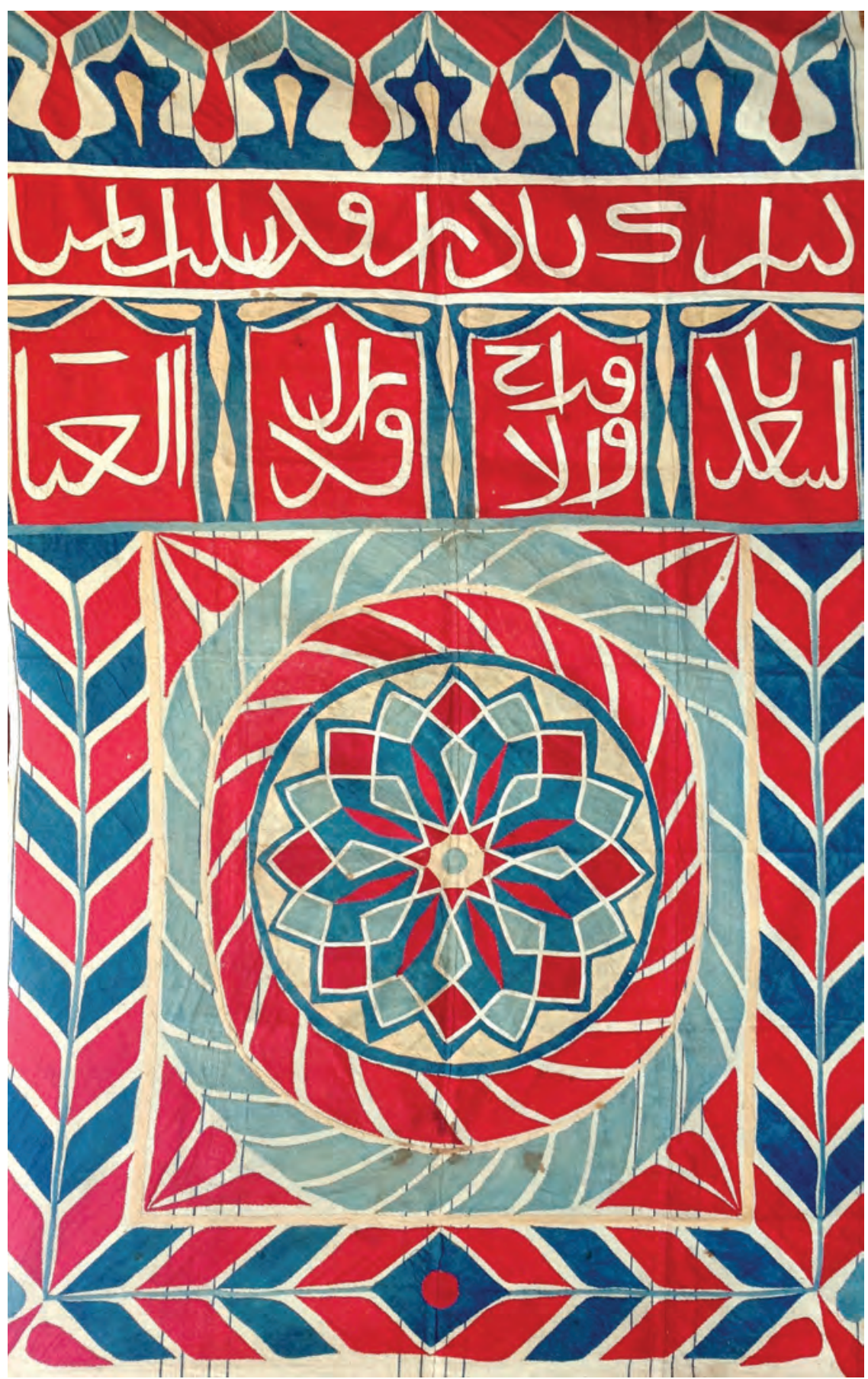

Figure 3. Unknown tentmaker, Khedival Khayamiya, c. 1890-1910, hand-turned appliqué cotton on linen, $2830 \times 1660 \mathrm{~mm}$

Photo: Bowker Collection, 2013 
Elaborate nineteenth-century Egyptian tents (fustat, diwan and suradeq), and individual khayamiya panels (siwan) are, however, featured in a handful of public and private collections around the world. ${ }^{10}$ The most comprehensive of these collections belongs to the Bowker family, followed by the survey collection in the British Museum, and the spectacular specimens in the Doris Duke Foundation for Islamic Art in Honolulu. Henri Matisse's extensive textile collection also featured a Khedival khayamiya panel, as depicted in his 1948 painting Interior with Egyptian Curtain and recorded in his studio in photographs by Henri CartierBresson in 1944 (Dumas 2004: 196-98). ${ }^{11}$

Such collections of Khedival forms of khayamiya are exceptions to the rule. Khedival khayamiya tend to be cumbersome in scale, and their use of Arabic calligraphy may have alienated those not literate in Arabic. As Sladen noted, dramatic wall sections or complete tents were 'too expensive' for most tourists (1911b: 106-07).

To engage with the Orientalist perceptions and expectations of Egypt held by foreign visitors (including tourists and soldiers), ${ }^{12}$ 'touristic' khayamiya were developed by the tentmakers in the late-nineteenth century. These feature Pharaonic and folkloric (balladi) images, as well as being smaller, cheaper and more symbolically accessible to Europeans. They are arguably more 'cheerful' for Western tastes than the earlier Khedivals.

Their Pharaonic content is indebted to books of reproductions published by Western authors, such as Georges Perrot and Charles Chipiez (A History of Art in Ancient Egypt 1883), in which conclusive links can be seen between the sequence of illustrated plates and adapted compositions used in touristic specimens. Tentmakers have reported that their regard for such appropriation is based not upon verisimilitude to the original, but instead the ability to interpret or combine multiple sources into a 'new' design - a trait that can also be seen when surveying Khedival khayamiya.

10 Khedival forms of khayamiya are notably well-represented in the British Museum, London; the Oriental Institute of the University of Chicago; the Semitic Museum at Harvard University; the Saunders Museum, Arkansas; the Islamic Arts Museum, Malaysia; and the Doris Duke Collection at Shangri-La, Honolulu.

11 The distinctive appliqué technique of the tentmakers may have influenced Matisse's use of painted paper cut-outs in his subsequent career, given similarities in the design and technical features of both art forms.

12 The Australian War Memorial features a 1944 photograph by Laurence Craddock Le Guay in which Australian soldiers are holding a large touristic khayamiya amongst other souvenirs collected in Cairo. Another photograph of the same era (by Dorothy Vines) depicts the interior of the Sisters' Mess Tent of the 2/1st Casualty Clearing Station in Amiriya, furnished with touristic khayamiya. 


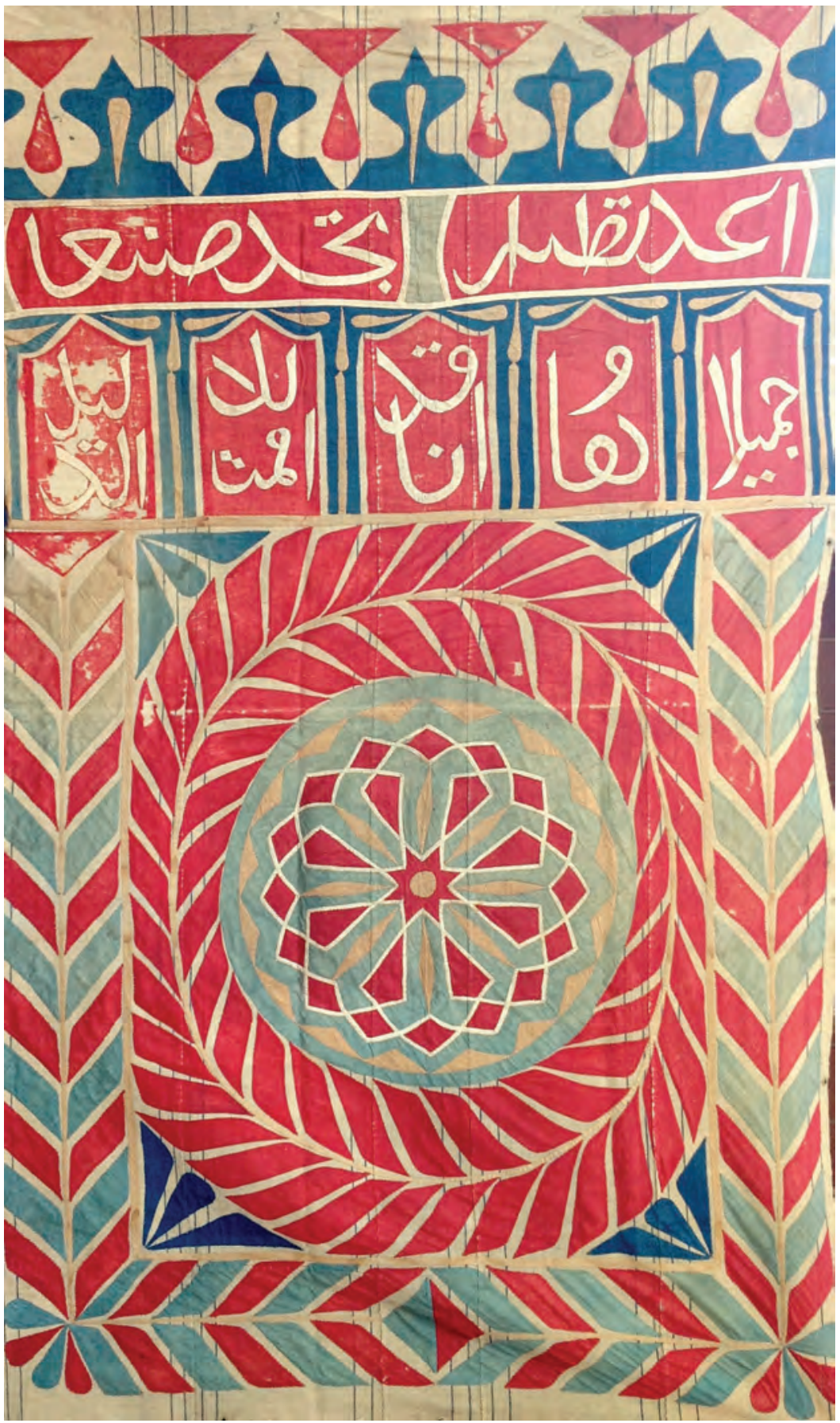

Figure 4. Unknown tentmaker, Khedival Khayamiya, c. 1890-1910, hand-turned appliqué cotton on linen, 2830 x $1660 \mathrm{~mm}$

Photo: Bowker Collection, 2013 


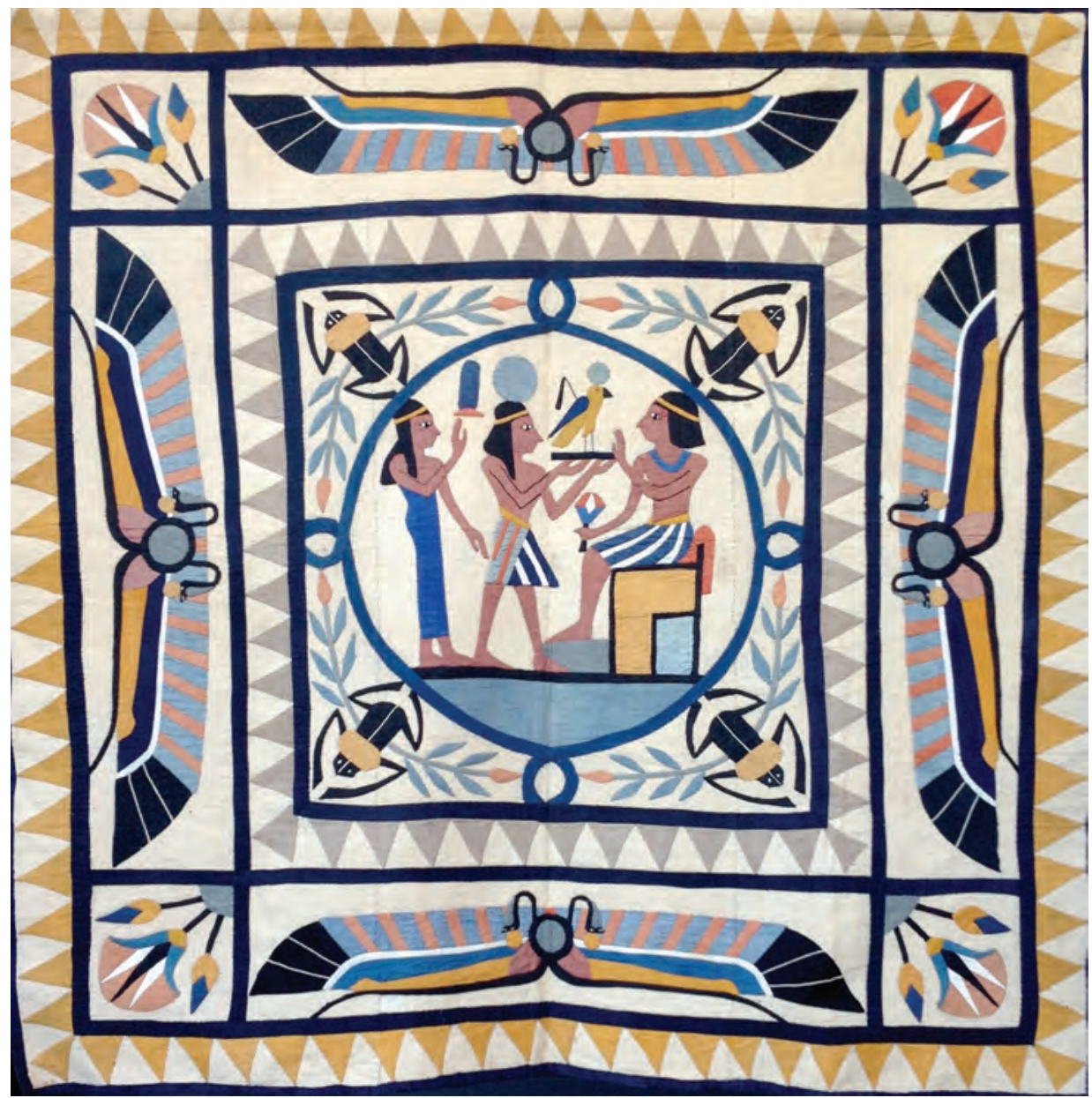

Figure 5. Unknown tentmaker, Touristic khayamiya, c. 1910-1950s, needle-turned cotton appliqué on linen, 1440 x $1440 \mathrm{~mm}$

Photo: Bowker Collection

Though touristic khayamiya have been linked by scholars and retailers to the popularisation of Egyptian themes after the excavation of Tutankhamun's tomb in 1922, they were in fact widely traded both in Egypt and on the secondary 'curio' or interior design market since the 1890s. They remain present on the international antiques market today, often described as 'vintage Egyptian tapestries'. ${ }^{13}$ Some have been linked by their retailers to Art Deco or Egyptian Revival trends, but examples have been found featuring influences from a range of twentieth-century design movements. They were also exported by retailers,

13 Most retailers appear only vaguely aware of their origin or context, and have inaccurately linked them to the Arts and Crafts movement, American folk art, or Egyptian Revival quilts. 
such as department stores and interior designers, as evidenced by Australian newspaper advertisements for David Jones and Myer (1930/1931), and Liberty of London (Gillow 2013: 93).

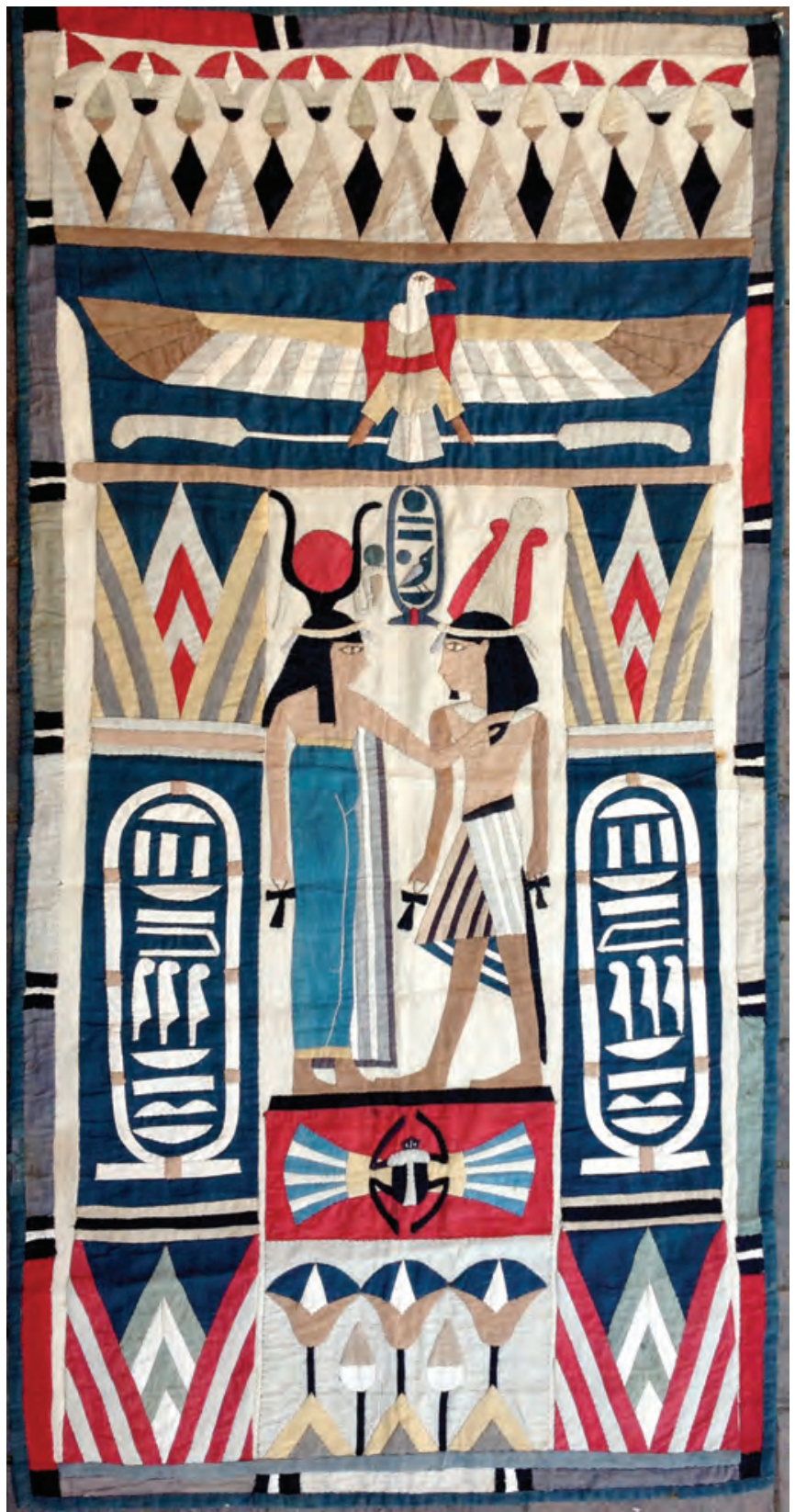

Figure 6. Unknown tentmaker, Touristic khayamiya, c. 1920-1930s, hand-turned appliqué cotton on linen, $670 \times 1350 \mathrm{~mm}$

Photo: Bowker Collection 


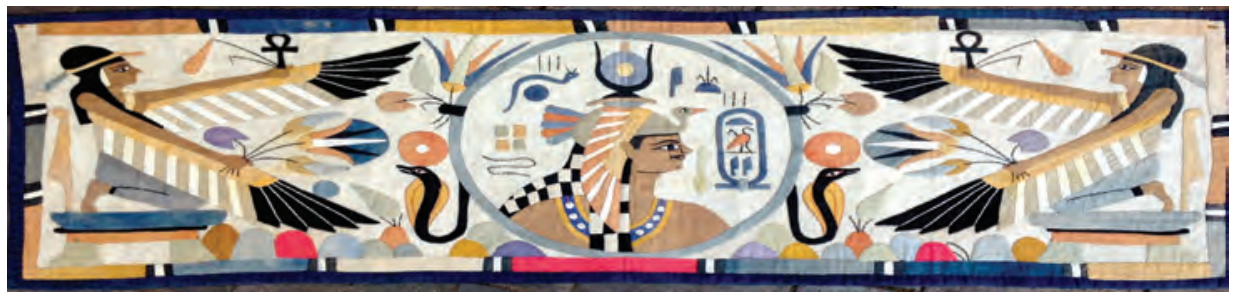

Figure 7. Unknown tentmaker, Touristic khayamiya, c. 1920-1950s, hand-turned appliqué cotton on linen, 1350 x $470 \mathrm{~mm}$

Photo: Bowker Collection

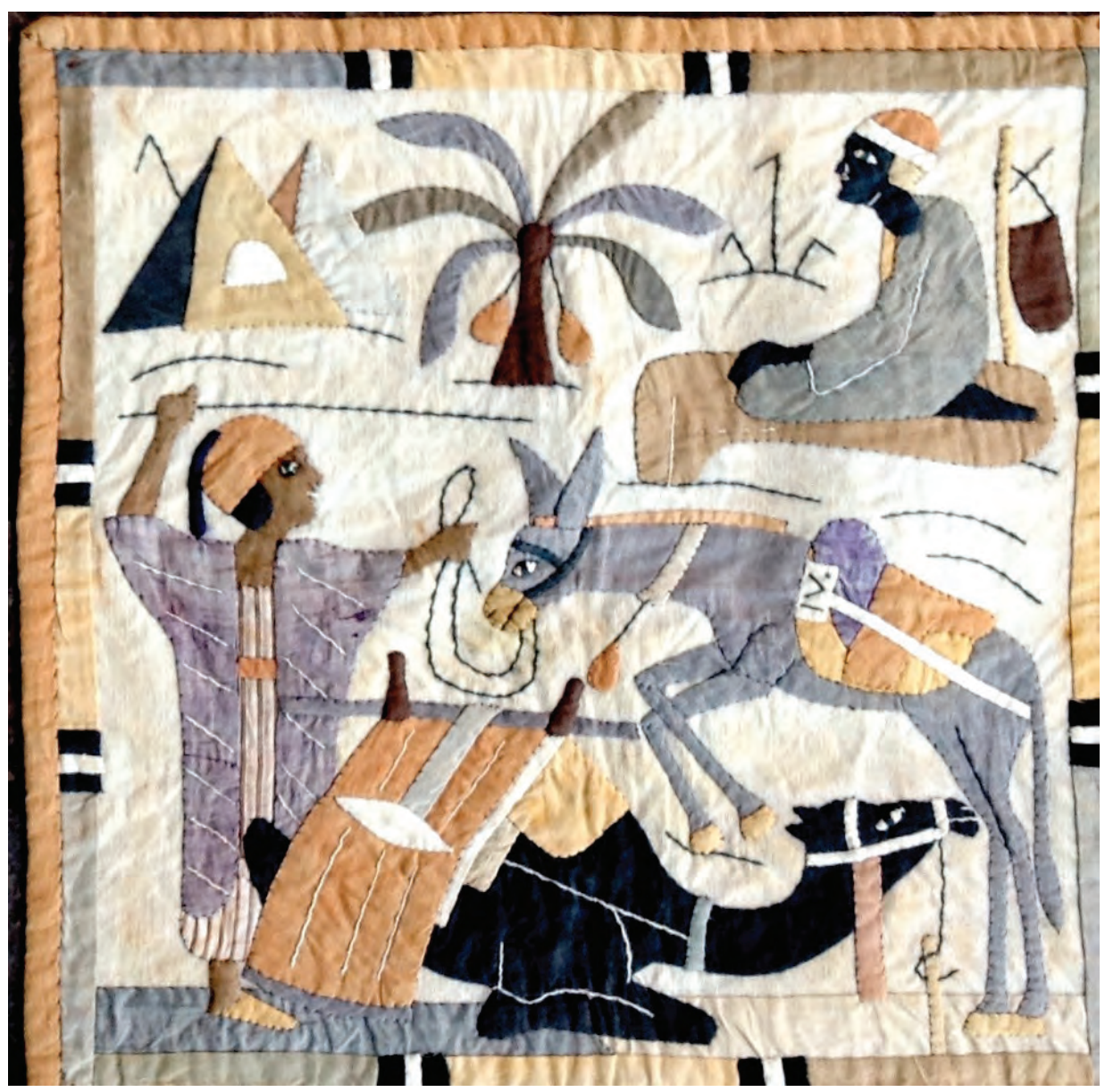

Figure 8. Unknown tentmaker, Touristic khayamiya (folkloric), c. 1910-1940s, handturned appliqué cotton on linen, 440 x $440 \mathrm{~mm}$

Photo: Bowker Collection 


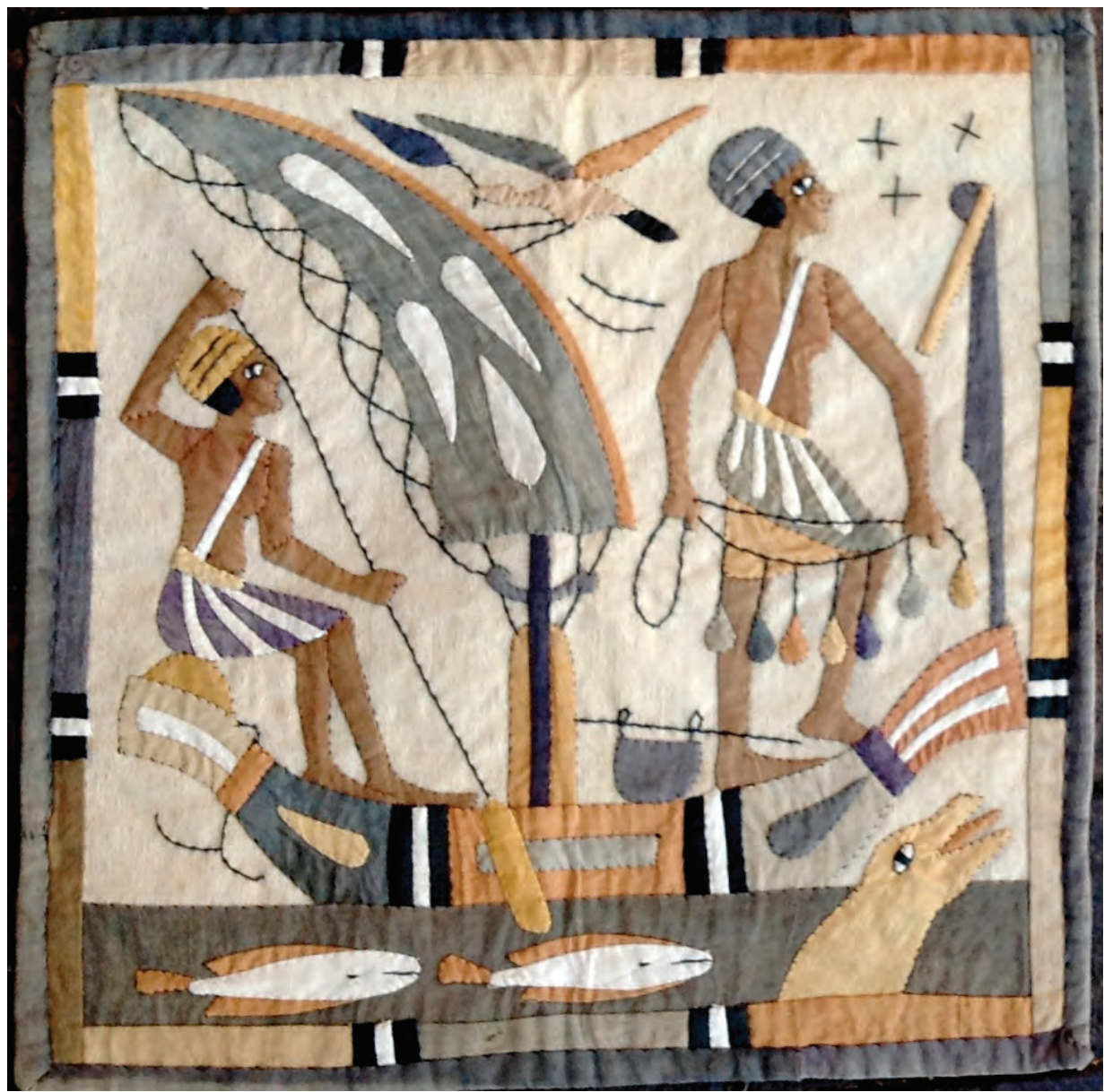

Figure 9. Unknown tentmaker, Touristic khayamiya (folkloric), c. 1910-1940s, needleturned cotton appliqué on linen, 440 x $440 \mathrm{~mm}$

Photo: Bowker Collection

The emergence of these objects as souvenirs, carrying designs that were quite unlike the abstract patterns and Islamic motifs that defined the Khedival khayamiya, was a dramatic departure from the previous roles of the khayamiya in Egyptian society. ${ }^{14}$ Unlike the Khedival preference for khayamiya of an architectural scale, the most popular format for touristic khayamiya are small square cushion-like panels, modest rectangular panels (typically $45 \mathrm{~cm} \times 100$ $\mathrm{cm})$, and door-sized panels or archways.

14 Some rare examples of hybrid Khedival-touristic forms are known, such as the archway in the collection of the Museum of Man in San Diego, acquired by Emily Michler in the 1890s. This is Khedival except for the panel featuring a Pharaonic vulture, which has been positioned in a manner that reflects its origin as an ancient architectural motif over temple and tomb entrances. 


\section{Issues facing khayamiya in Egypt}

The architectural scale of khayamiya is still relevant to its persistent cultural value in Egypt. They are used as a colourful spectacle to distinguish all manner of festivals and celebrations, including weddings, funerals, Moulid festivals, the iftar feasts of Ramadan or the farewell and reception of Hajj pilgrims, as well as graduations and political rallies, and even just for ornamental value. In practical terms, khayamiya is still seen as a versatile outdoor textile, to be hired out and repaired if needed. Since the 1970s this function has been served by printed-pattern fabrics that imitate the designs of authentic khayamiya appliqué. Lighter and cheaper than appliqué panels, these fabrics have undermined both the need for and social status of handmade khayamiya. Many tentmakers now sell lengths of the 'imitation khayamiya' alongside their handcrafted appliqué in utilitarian acceptance of this new product. ${ }^{15}$

Other Egyptian applications of khayamiya have been discontinued. Perhaps the most status-affirming historic application of the khayamin's skills was the making of sacred Kiswa textiles for shrouding the Ka'ba, as well as the camelborne ceremonial canopy known as the mahmal, once used to parade the kiswa to Mecca. ${ }^{16}$ Local festivals that once marked the end of the Nile floods ceased after the construction of the Aswan High Dam, removing the recurring need for khayamiya panels and pavilions (siwan and suradeq).

Though texts (Sladen 1908: 391), photographs and paintings reveal calligraphic Khedival khayamiya panels in use inside affluent Egyptian houses during the late-Ottoman period, this application is rarely seen today amongst Egyptians. The finest handmade work retains its association with funerals, which makes it unwelcome in domestic settings, despite the visual appeal and its iconic role in Egyptian heritage. ${ }^{17}$ Interestingly, only touristic khayamiya (and their descendants) are now made with the expectation that they will be displayed inside homes. This has resulted in a commercial imperative towards finer work, in terms of design, subject matter, composition, colour use, overall scale, and stitch quality.

15 Applications of this fabric have been seen across a variety of products, including clothes, upholstery, bags, books, and interior design, as well as awnings and tents in the manner of true khayamiya. In 2006 Tonya Ricucci documented a damaged hand-appliquéd khayamiya bearing patchwork repairs using colour-matched 'imitation khayamiya' fabric, demonstrating the interchangeability between these approaches to khayamiya.

16 Kiswa are grave shrouds laid over important sarcophagi or mausoleums, but most famously appear as vast black, gold-embroidered, drapes over the cube-like structure in the heart of Mecca called the Ka'ba. The Ka'ba is the point towards which all Muslims face when they pray, as indicated by the position of a mihrab (prayer niche) in every mosque. The mahmal was a tent-like structure carried from Cairo (and other cities) to Mecca, accompanying pilgrims from that city on the Hajj. Although some believe the mahmal was the 'package' for the kiswa, this is mistaken - it was usually empty and served as a symbolic centrepiece for a ritual parade.

17 Godfrey Goodwin describes the use of 'Ottoman grave-tents' and their associated symbolism in Egypt (1988: 61-69). Jenny Bowker also notes that wealthy Egyptians 'just do not think the work is beautiful. [Instead, they] aspire to the faded elegance of old French tapestries, and think khayamiya too bright and brash' (Bowker 2013). 


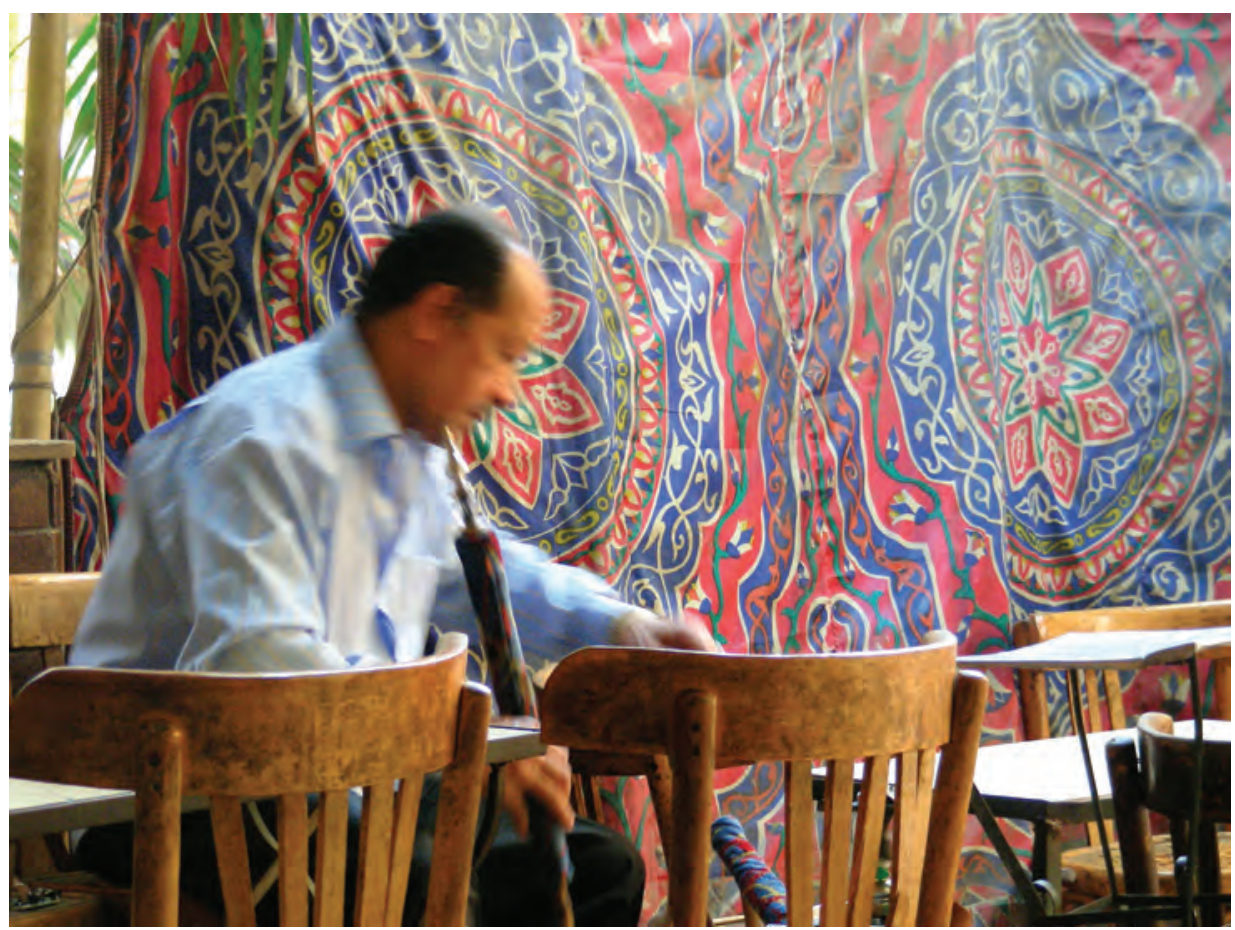

Figure 10. Imitation khayamiya in use in Cairo

Photo: Jenny Bowker, 2008

To accommodate new cultural and commercial imperatives, the tentmakers have repeatedly reinvented their craft. Adaptive and entrepreneurial, they have focused their craft on the preferences of international audiences. The result is a diverse range of styles within contemporary khayamiya that combine the practical design of the touristic with appropriations from Islamic art, especially derived from ornaments from mosque architecture.

Collectively, the changes in the use and production of khayamiya between the mid-nineteenth century and the present are remarkable. They have adopted forms so far removed from the original Khedival khayamiya that many of the living Egyptian tentmakers are unaware of the full extent of their own visual and material heritage. This distance threatens the 'symmetry of opportunity' between khayamiya and quilting, for as the tentmakers are exposed to design influences from other cultures, they will adopt aspects of them. If familiarity with the foundations of their own craft can be restored through exposure to khayamiya made beyond living memory, then the tentmakers may respond to new influences without compromising the core design integrity of khayamiya as a unique textile art. 


\section{Engagement with khayamiya by quilters since 2000}

The emerging interest in khayamiya at a popular level by quilters and in terms of subsequent research by academics marks a critical point in the history of this craft.

Betty Wass conducted field research into the socio-cultural continuity of khayamiya in 1979, focusing on the touristic forms typical at that time. ${ }^{18} \mathrm{Her}$ research notes also reference two Arabic theses prepared in 1972 and 1975 (cited in Gagnon 2002: 138-41). Wass's fieldwork was further developed by Gagnon towards her master's thesis in 2002, which contributed to Gagnon's 2003 article 'Egyptian appliqué' in Uncoverings, the research papers of the American Quilt Study Group. Gagnon thus published the first academic framework dedicated to the touristic forms of khayamiya.

Gagnon's investigation positioned touristic khayamiya within contemporary critical discourses of tourist arts. Gagnon's research is valuable not only for her systematic approach to material analysis and its implications for future khayamiya research, but for arguing persuasively for the cultural authenticity of this form of khayamiya (Gagnon 2002: 5-17). In brief, its metamorphosis was a necessary adaptation in order for this craft to survive:

Egyptian tourist appliqués are traditional because they are an innovation that embodies both continuity with the past and adaptation, through a process of performance as the tentmakers hand down their craft from generation to generation. This process of adaptation and confirmation is the process of cultural construction, it is what keeps history moving forward into the future. In following, Egyptian appliqués are authentic because tradition is the vehicle through which objects become authentic. Authenticity is not only negotiated in the production of the toured object, it is also formulated in the experience of the tourist. (Gagnon 2002: 116)

It is noteworthy that Gagnon is a quilter, and it was her interest in touristic khayamiya in the collection of the University of Rhode Island that prompted her investigation into this craft. She also remarks upon the perception of integrity and authenticity of touristic khayamiya as a craft when collected by quilters:

As a quilter, [she] was drawn to an art form that she was familiar with and which she understood, particularly concerning craftsmanship: 'What attracted me to this is that it was all done by hand.' She purchased [two] out of respect for the workmanship of the 'artist' ... Intuitively, this informant recognized the standards of craftsmanship outlined by the tentmakers and verified through this study. (Gagnon 2002: 122)

Gagnon's connection between khayamiya and quilting is paralleled in the work of Jenny Bowker, who first encountered the work of the tentmakers while visiting

18 This was partly published in Islamic Art from Michigan Collections (1982), and several of Wass's fieldwork photographic records can be seen via the online collection of the University of WisconsinMadison. 
Cairo in the 1980s. By 2005, when she moved to Cairo, Bowker was a wellknown professional quiltmaker, and immediately saw links between quilting and the appliqué of the tentmakers.

I saw the quilt shows as a perfect audience for the men, as the fact that there were parallels - and because much of the audience would have tried hand stitching - meant that the audience would be aware of just how difficult the work was to do, and because of this, an awareness of the skill the men applied to what they made. (Bowker 2013)

I had intended to take only tentmaker work - then realised that one of my favourite things to do was just watch the men work. They use 12-inch shears, heavy crowbar needles, and hanks of loose fabric - and their big hands tuck and trim and stitch so fast that photos are just a blur of movement. (J. Bowker 2010: 56)

Drawing on her network in the Australian quilting community, Bowker curated the first international exhibition dedicated to contemporary tentmaker appliqué. ${ }^{19}$ Exhibitions curated by Bowker have now been held in Australia, France, Spain, the United Kingdom, and several locations in the United States, including major American Quilter's Society (AQS) exhibitions at Grand Rapids, Lancaster, and Paducah. Tentmakers have been present to demonstrate their skills and speak on behalf of their profession (and fellow Egyptians) on every occasion.

To reach the most diverse and receptive audience for this craft, Jenny Bowker's exhibitions were held as events of special interest within large quilting exhibitions (at state or national scale). These were commercial exhibitions from the perspective of the tentmakers, who were paid all proceeds once their work had been sold. All accommodation and transport costs for the participating tentmakers were covered by sponsorship. In 2013 an alternative model was used to bring the tentmakers Ekramy Hanafy and Hany abd el-Qadir to Canberra, in which tuition fees for classes in their hand-appliqué techniques covered their airfares to Australia from Cairo, and their payment was made through a silent auction of their own khayamiya at a Canberra Quilter's Inc meeting.

In 2012 the tentmakers and the AQS collaboratively developed an unprecedented three-year contract to exclusively promote and sell the work of the tentmakers in the United States. The work is purchased directly from the tentmakers in Cairo on behalf of the AQS, then sold to American audiences with a markup that covers the costs of transport and accommodation for the participating tentmakers and the work being exhibited. This should provide the entire street with a reliable income source and generate awareness of khayamiya in the US market. (Bowker 2013)

19 Khayamiya was featured as a decorative carpet-like 'prop' within the 'Assuan Village' in the Earl's Court Exhibition in London in 1907, according to postcards depicting this colonial ethnographic exhibit. Bowker's work, however, was the first exhibition to display khayamiya for their own sake, on its own terms. 

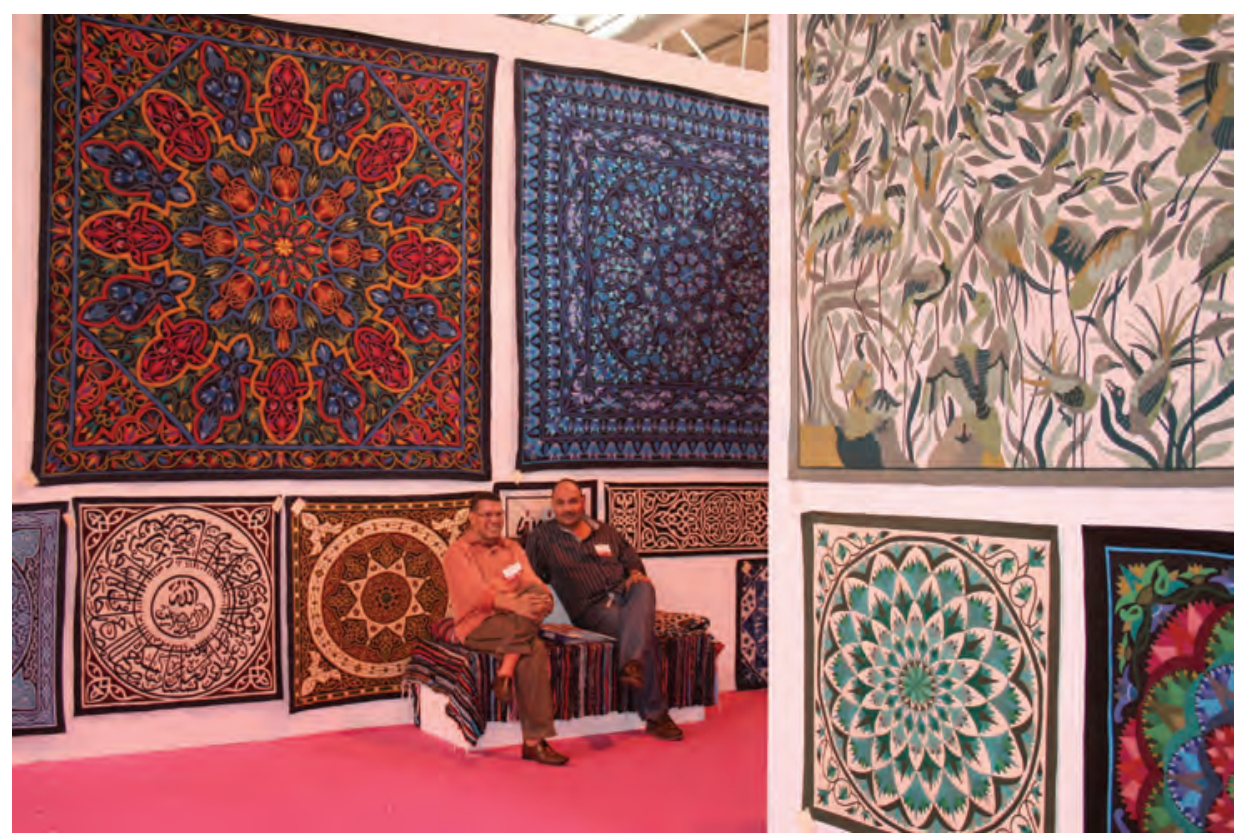

Figure 11. The Tentmakers of Cairo exhibition at the Birmingham Festival of Quilts, 2011

Photo: Jenny Bowker

From the first tentmaker exhibition at the Australasian Quilt Convention in Melbourne in 2007, founding principles were established to ensure fair representation of the tentmakers in all subsequent exhibitions. The most important of these was to ensure that all tentmaker businesses were represented in every exhibition, and featured both a high standard of work and the diverse design repertoire of the tentmakers. The tentmakers are highly competitive with one another and protective of their designs, so this was a challenging process.

It is essential that English-speaking tentmakers are present at every exhibition. ${ }^{20}$ These men engage audiences with their hand-appliqué techniques (as their speed and skill consistently strikes quilters with surprise), and explain the design, use, and context of their work in Egypt. These are aspects of khayamiya retailing which developed independently in Egypt, where English-speaking tentmakers typically work in public on the Street of the Tentmakers whilst Arabic-speaking craftsmen work 'behind the scenes' in nearby workshops. The implication of their participation is that only tentmakers who can acquire passports and visas can lend their voice to international exhibitions. A degree of charisma and public speaking skills are also required, but this is also true for tentmakers working as retailers in Cairo.

20 The first exhibition to not feature a living tentmaker was the author's exhibition Khayamiya: Khedival to Contemporary, which used a short video by Kim Beamish to lend Hossam Hanafy's voice to the exhibition. 


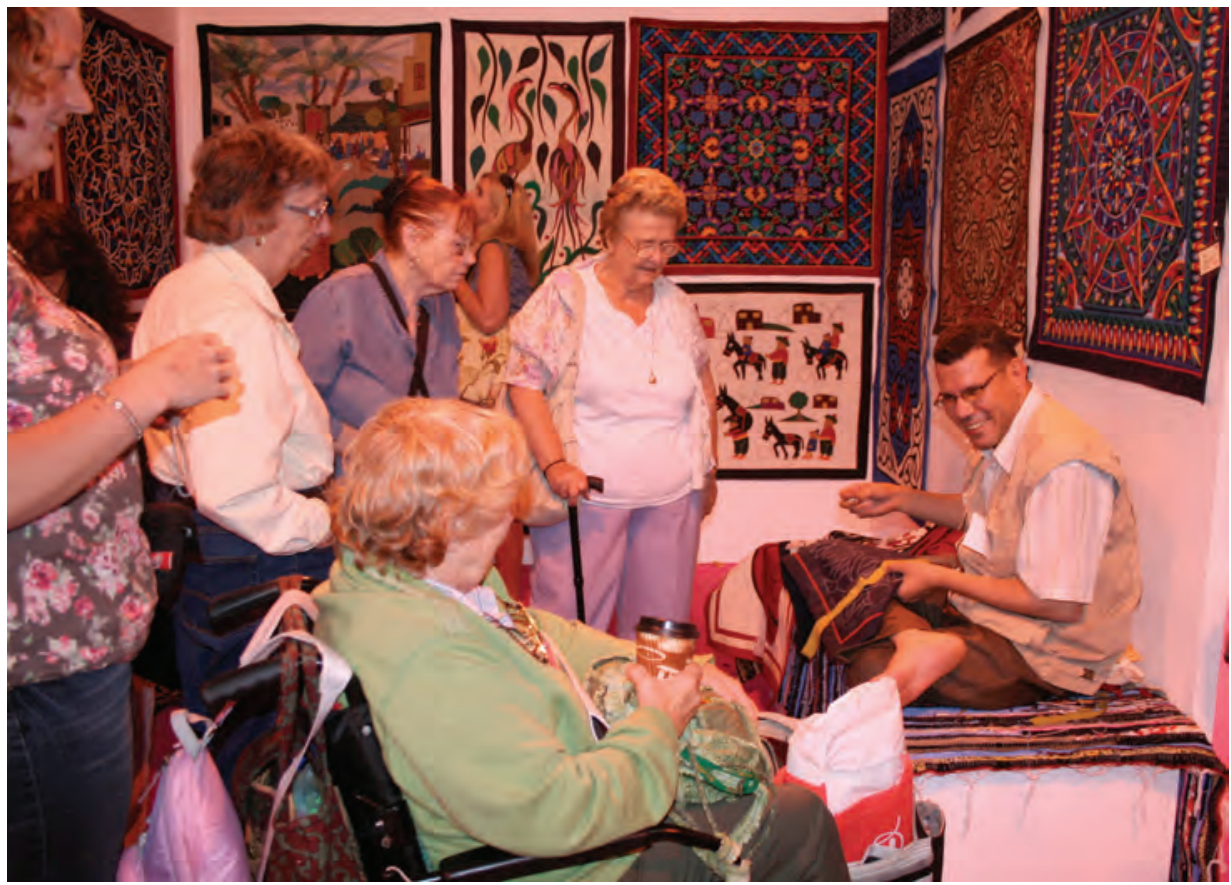

Figure 12. Hosam Hanafy presenting khayamiya appliqué to quilters in Birmingham, 2011

Photo: Jenny Bowker

Khayamiya in quilt exhibitions feature tentmaker work alongside tentmakers working. Given historic precedents for such 'ethnic' Egyptian demonstration work, such as colonial world expositions, the 'display' of such craft practice is considered with great scrutiny. Their responses to questions are entirely their own, sometimes assisted by a translator if one is available. The tentmakers wear exactly what they would wear normally, and they make what they would normally make in Cairo. As Bowker explained when asked about the significance of their physical participation:

It is important that the men are there to demonstrate in the exhibitions I have organised. It is partly to let people see how fast they stitch, how simple their tools are, and how skilled they are - but also to establish their clear ownership of the work. One thing that I have truly sought to change is that all work to be sold in exhibitions is signed. At first we asked for the tentmaker to sign it, and found that some shops were simply making up names rather than giving credit to a worker. Then we asked for shop names, followed by the stitcher's name, and it started to work. This gives ownership and additional provenance for the work, but many tentmakers still cannot see a lot of point in adding their signatures. (Bowker 2013)

The term khayamiya is used when describing this craft form, but this Arabic term is less easily remembered (and incongruously spelt) compared to English 
equivalents, such as 'tentmaker appliqué', or even 'Egyptian quilts'. ${ }^{21}$ The exhibition title often used in quilt contexts - Stitch like an Egyptian - borrows from the conventions of quilt workshop titles, both as a literal description and pop cultural pun. As khayamiya becomes more familiar to Western audiences, the tentmaker's own term for their craft may be used more widely in English.

The patronage of quilters has also been crucial to the successful crowdfunding campaign for the independent feature-length documentary The Tentmakers of Chareh el-Khiamiah, currently being produced by the Australian filmmaker Kim Beamish. ${ }^{22}$ This is the first documentary account of the life and work of the tentmakers from their own perspective, including their active engagement in quilt exhibitions beyond Egypt. Much as this paper does, Beamish seeks to increase awareness of contemporary khayamiya beyond quilting audiences, and situate their collaboration with quilters as the most recent manifestation of the tentmaker's ongoing engagement with international audiences. Several other projects are also currently underway to bring the quilter's endorsement of khayamiya to other Western and Egyptian audiences, ultimately seeking to build a more sustainable commercial, academic and cultural basis for the tentmakers of Cairo.

\section{Quilts and khayamiya: Relationship analysis}

When referring back to Murray's call for a re-evaluation of global collaborations between crafts, in terms of patronage and peer review, the tentmakers could not find a group more ideally situated than the quilters. Quilting is international, quilters recognise excellence in craft, and quilting audiences appreciate both long-held tradition and experimental innovation. Quilters combine an experiential pragmatism with a sincere appreciation of craft as a labour and an aesthetic. This is translated in both popular and academic approaches to quilting, and provides an appropriate foundation for the study of khayamiya.

Quilters have generated independent platforms for the display, peer review, and publication of quilting as craft and contemporary art. Quilting is both a craft and a thriving industry, simultaneously demanding the recognition of its past and encouraging the sustainable continuation of the work to new generations. By contrast, the tentmakers are a small and competitive group of skilled workers, driven by professional demand but culturally and geographically isolated. The 'amateur' or 'hobbyist', so valuable to quilting as a popular craft, simply does not exist amongst the Egyptian tentmakers. Broadly speaking, quilting is still perceived as women's work, but khayamiya are primarily the products of sewing men. ${ }^{23}$

21 Note that the latter term is never used by the curators of these exhibitions. 'Egyptian quilt' is a descriptive adaptation developed by Western quilting audiences and widely seen on social media, such as Facebook.

22 The film's website can be seen here: http://www.chareh-elkhiamiah.com/ (Global release in 2014/2015).

23 Gender is a striking difference between the khayamin and contemporary quilters. Tentmakers, with few exceptions, are men. Khayamiya is conventionally seen by Egyptians as men's work. The 


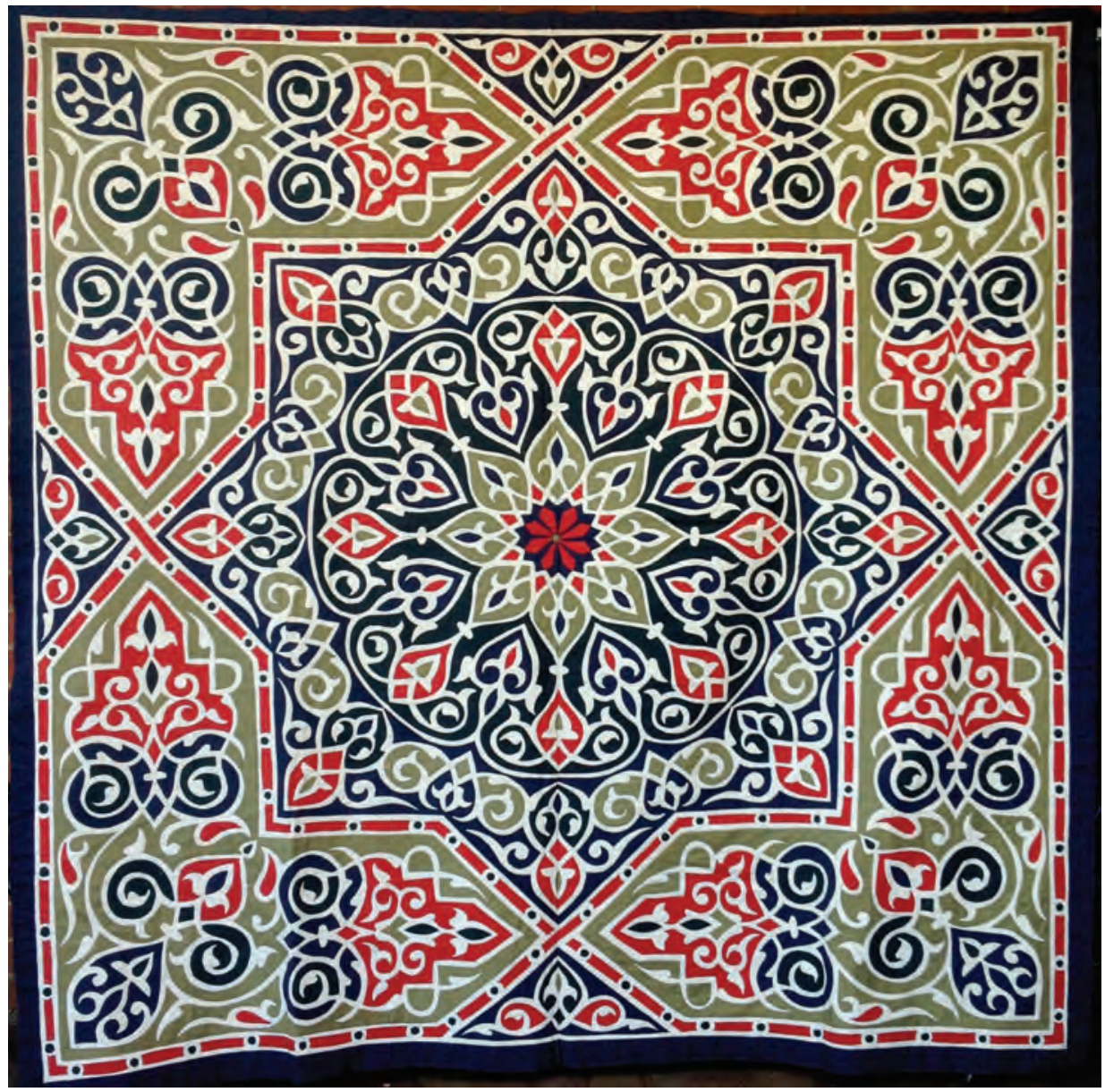

Figure 13. Mohammed Hashem (Senior), Khayamiya, c. 2012, needle-turned cotton appliqué on linen, $2230 \times 2230 \mathrm{~mm}$

Photo: Bowker Collection

The affinity between khayamiya and quilts consists of similarities and juxtapositions. Whilst quilts have faced the challenge of being perceived as horizontally displayed utilitarian objects, khayamiya have always been accorded with the tapestry-like 'dignity' of vertical display, even in a strictly functional context - though perhaps this has been offset by their exposure to harsh outdoor conditions (dust, heat and direct sun) versus the indoor security afforded to quilts. Quilts serve private needs within domestic contexts, whilst khayamiya were public displays for a wide range of outdoor ceremonies. Quilts

reverse is true of quilters. Both gender discrepancies are the product of complex cultural gender roles between Egypt and the West, manifested in the places where quilts and khayamiya are made, the functions expected of these objects, and the social values of quilting and khayamiya respectively. 
are privately owned objects that can aspire to retire as family heirlooms, but khayamiya screens are hired objects for public display, sometimes repaired but usually discarded as rags when faded.

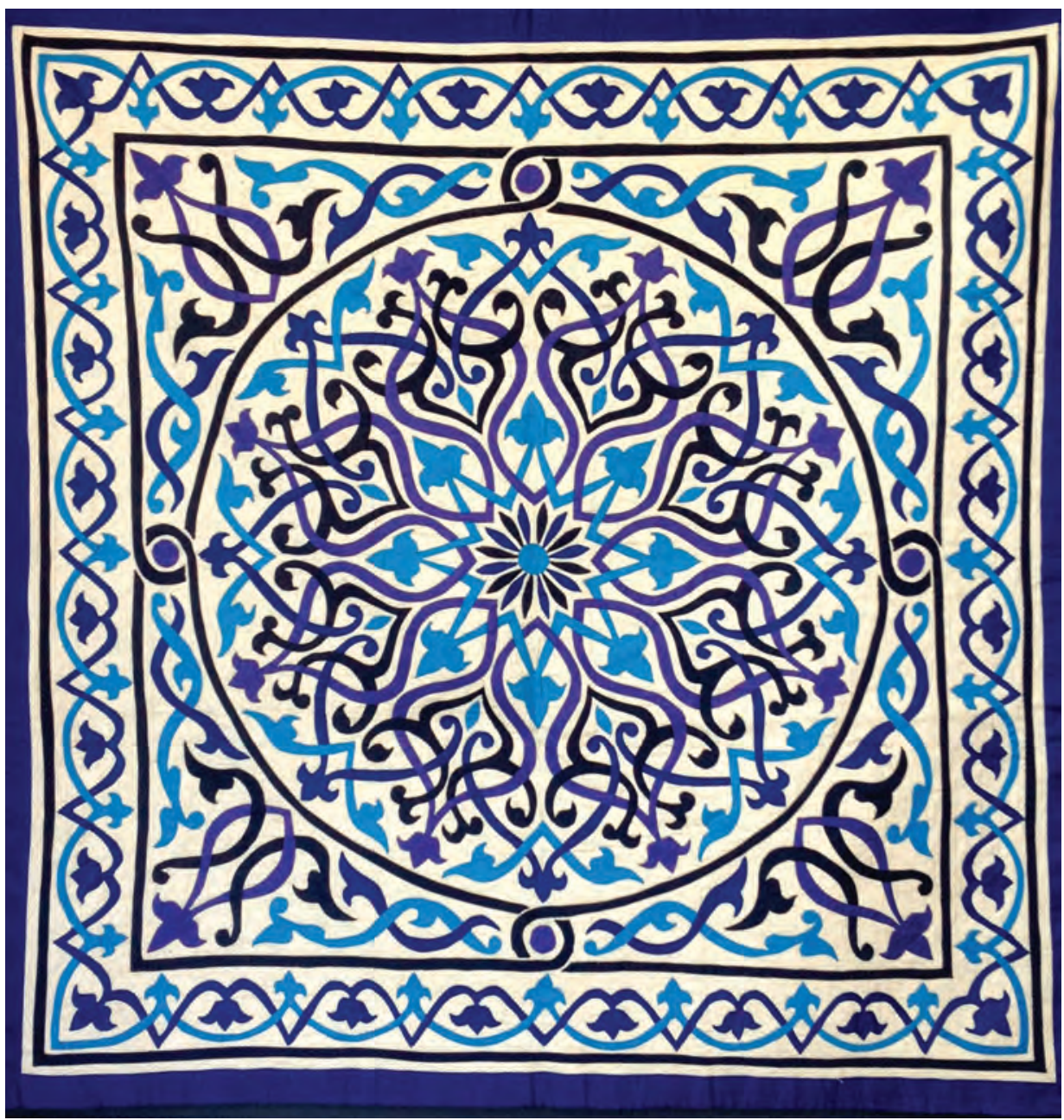

Figure 14. Hossam Hasham, Khayamiya, c. 2010-2012, needle-turned cotton appliqué on linen, $1200 \times 1200 \mathrm{~mm}$

Photo: Bowker Collection

Both crafts have struggled to be seen as 'art'. Neither has yet found their due representation in museums and art galleries, though this is changing especially for quilts. Both are a form of folk art, ancient in origin, and made with similar techniques, materials and technology. They are both concerned with display, ornament, and embracing the power of decorative arts to transcend the functional into the spectacular. For much of their history, both quilts and khayamiya were made anonymously. They both embrace a complex heritage, 
and recognising their shared context as contemporary craft is mutually beneficial. Their interactions thus present the critical 'symmetry of opportunity' requested by Murray. Regarding Murray's comments on Western perceptions of innocent primitivism, the tentmaker's craft is not regarded with such praising condescension - rather, it demonstrates continuity with historic skills that cannot be delegated to sewing machines.

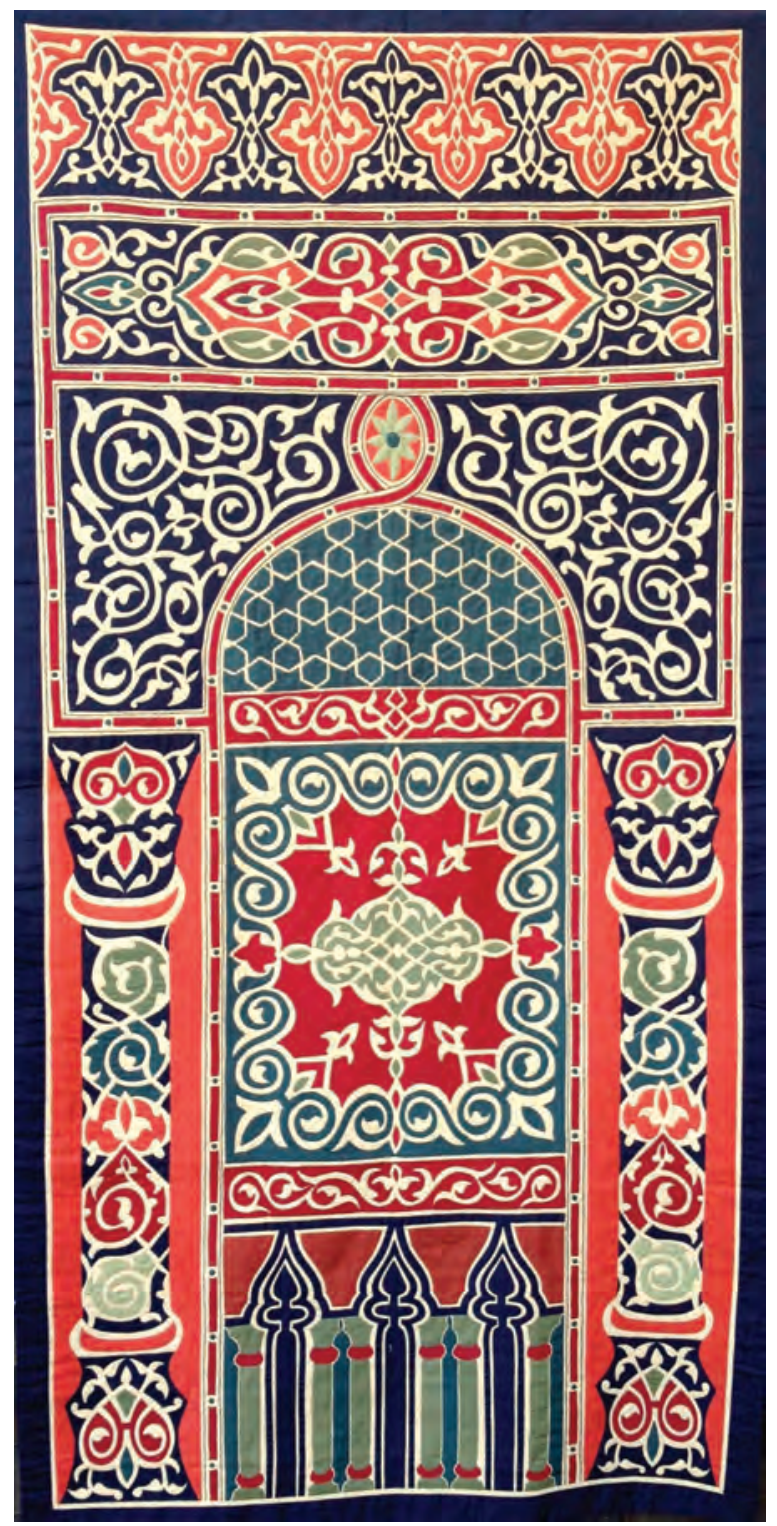

Figure 15. Tarek Fattoh, Mihrab, c. 2009-2011, needle-turned cotton appliqué on linen, $1890 \times 950 \mathrm{~mm}$

Photo: Bowker Collection 
Further, the significance of interaction with quilters beyond Egypt has real effects on the esteem of khayamiya within Egypt, especially amongst the tentmakers themselves. As Bowker mentioned when interviewed:

One of the things that stood out for me is not that the world has responded so brilliantly to seeing what the tentmakers can do, but that the tentmakers have seen for themselves that what they do has importance and is beautiful. They are walking taller, and suddenly Egypt's lack of interest in their art form does not really matter any more. (Bowker 2013)

Bowker described the immediate effects of this recognition as illustrated by the reactions of the tentmakers at the 2007 convention in Melbourne after being swarmed by crowds of fascinated quilters:

Both [Ahmed Naguib and Ayman Ahmed] are so utterly humbled by the interest of Australians in what they had believed was an unimportant and menial skill. (Bowker 2007)

The challenge that is now facing the tentmakers of Cairo is the ability to promote their own voices internationally, addressing the aspects of their heritage and craft practice which resonate with Western audiences in particular. Although they have demonstrated the capacity to change their craft to suit new audiences, their ability to independently organise their own participation in international exhibitions has not yet been tested. Should this happen, the balance of complex commercial interests in the Street of the Tentmakers will be tipped towards that entrepreneurial tentmaker. It is possible that misjudging the design relationship between 'exotic' khayamiya and 'familiar' quilting could jeopardise the mutually beneficial symmetry between these craft disciplines. For this reason, increasing the tentmaker's awareness of their heritage - including Khedival khayamiya designs from beyond living memory - will prove vital in establishing their cultural foundations for future international engagement. To sustain integrity, whatever form they may take in the future, the designs of khayamiya can never be anything other than 'Egyptian'.

Tentative signs of a revival are now emerging in the tentmaker profession, which had been in decline since at least the 1980s (Feeney 1986). Trained tentmakers have returned from alternative careers to support family businesses; others because their previous professions provided poor conditions and lower social status (Ramadan quoting Saeed Mokhtar 2010). Some have tertiary qualifications, and have chosen this profession over other careers because they enjoy the nature of this craft (Bowker 2013). On the basis of their entrepreneurial pursuit of new designs and clients, and following international exposure, some tentmakers have recently opened their own khayamiya shops, independent of their former employers (such as Hany abd el-Qadir and Tarek Abdelhay), which has ruptured traditional employer-apprentice workshop relationships. Few young Egyptians, beyond the tentmaker families, however, are being trained in khayamiya craft methods with the expectation of developing careers in this field. 
This is a contrast to two photographs from the turn of the nineteenth century, which depict large khayamiya panels sewn in simultaneous collaboration by adult men and boys. ${ }^{24}$

\section{Conclusion}

When the touristic succeeded in market terms, it could be said that the Egyptians lost 'their' khayamiya. In an ideal future, perhaps demand for handmade khayamiya will be maintained not by foreign interest, but by and for Egyptians. Given the economic situation of many Egyptian homes, this is not a likely outcome. The international support of this craft is essential to its survival and continues to drive adaptations which ensure that khayamiya remains a contemporary manifestation of Egyptian craft and visual culture.

The emergence of both academic and popular interest in the Egyptian tentmakers celebrates the history of Egyptian craft and design, and demonstrates the potential for the khayamin to determine their future on an international stage. Their unique craft has moved from their original local market through to an international audience of collectors, scholars, and appreciators from a diverse range of backgrounds. Once quilters endorsed the tentmakers at a popular level, academic interest could promote khayamiya to audiences with other means of influencing the institutional recognition of this art form. The recognition of khayamiya as an important and vital art form to regard and display within a cultural context of national identity and social history would be a positive development not only for the tentmakers, but as a case study in international collaboration that has not compromised the integrity of ethnic crafts.

The Egyptian tentmakers have shown how the usage, composition and production of cultural goods has shifted and changed to address international market demand for their craft. This has led to the re-evaluation of their craft as a cultural and design practice, and prompted new interest in their history. Quilters have played a significant role in this re-evaluation, but maintaining the memory of khayamiya's origins will be essential to the ongoing vitality of khayamiya as an Egyptian art form with a global audience. 
craft + design enquiry

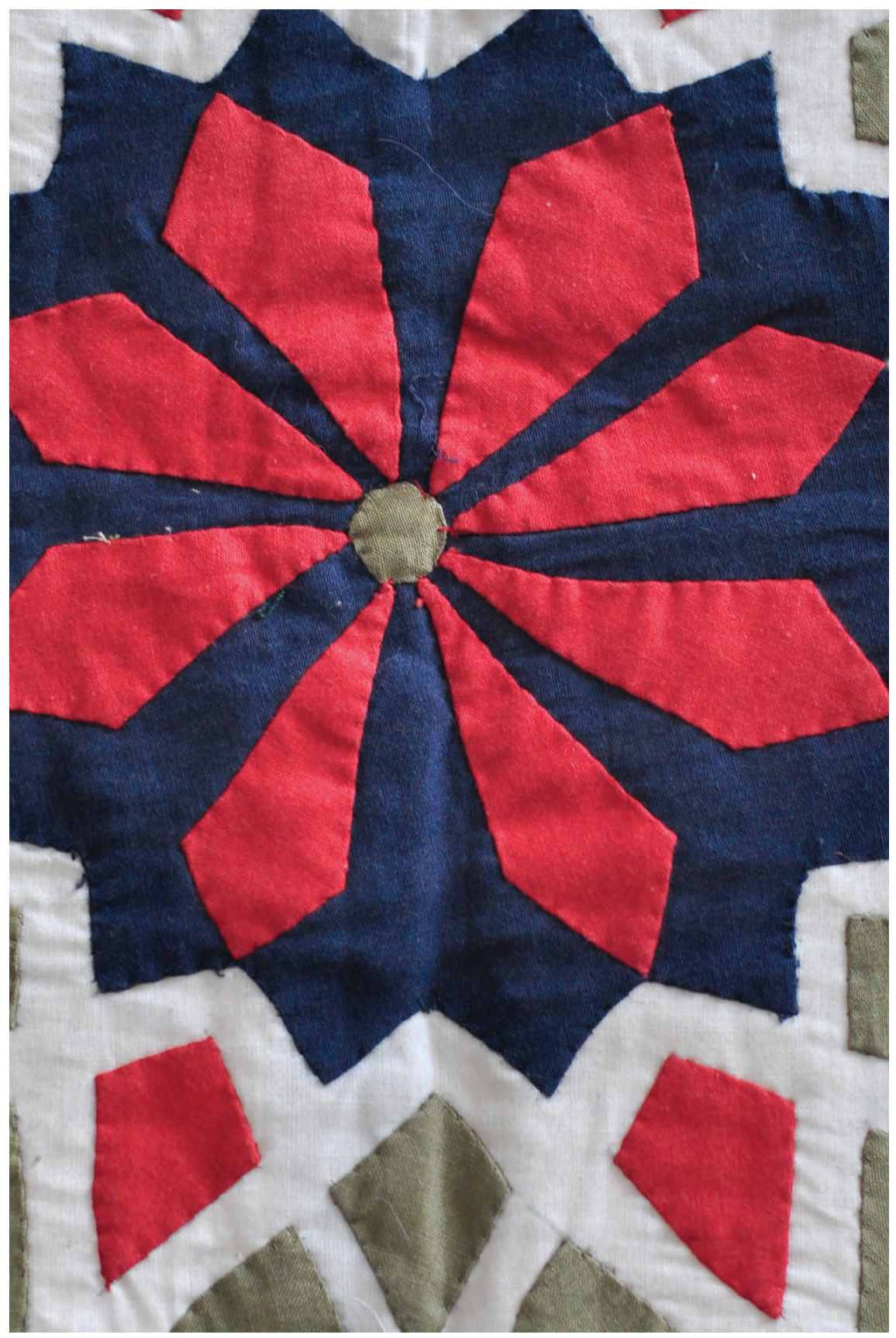

Figure 16. Detail from a contemporary khayamiya (2010) by Mohamed Hashem in the Bowker Collection

Photo: Aaron James Neal 
Dr Sam Bowker lectures in Art History and Visual Culture at Charles Sturt University in Wagga Wagga. He is also the curator of the groundbreaking touring exhibition Khayamiya: Khedival to Contemporary, and is writing the first substantial book on Egyptian khayamiya.

\section{References}

Abdul-Yazid, A. 2003, 'Khayamiya: The texture of life and death', AlArabi Magazine, 7, no. 536, viewed June 2013, http://3arabimag.com/ SubjectArticle.asp? ID=11447.

Al-Sayyed, H. 2012, 'The Egyptian art of tent-making', Ahram Online, 24 July, viewed June 2013, http://english.ahram.org.eg/NewsContent/32/99/48580/ Folk/Special-Files/The-Egyptian-art-of-tentmaking.aspx.

Aly Shawky, A. 2011, 'Streets of Cairo: Tent-making and endangered crafts around Khayamiya', Egypt Independent, 13 August, viewed June 2013, http://www.egyptindependent.com/news/streets-cairo-tent-making-andendangered-crafts-around-khayamiya.

Ammoun, D. 1991, 'Tentmaking', Crafts of Egypt, American University of Cairo Press.

Andrews, P.A. 1997, Felt Tents and Pavilions: The Nomadic Tradition and its Interaction with Princely Heritage, Koelner Ethnologische Mitteilungen, London: Melisende.

- - 1999, Nomad Tent Types in the Middle East, Wiesbaden: Ludwig Reichert.

Atasoy, N. 2000, Otag-i Humayun: The Ottoman Imperial Tent Complex, Istanbul: Aygaz.

'Australian exhibition of women's work' 1907, Queenslander, 21 Sept. p. 6, viewed June 2013, http://nla.gov.au/nla.news-article22273768.

Barakat, H. 2003, Beyond Boundaries: Tents of the Islamic World, Kuala Lumpur: The Islamic Art Museum Malaysia.

Bowker, J. 2007, 'Looking at the Australasian Quilt Convention through Egyptian eyes', Vic Quilter - TheVictorian Quilters Journal, July 2007, pp. 28-29.

- - 2010, 'Teaching, travelling and traditions', Machine Quilting Unlimited, vol. 15, no. 3, pp. 56-60.

- - 2012, Stitch Like an Egyptian: The Tentmakers of Cairo Exhibit,, catalogue, American Quilt Society.

- - 2013, 'The tentmakers of Chareh El Khiamiah - the film', Down Under Quilts, no. 158, pp. 54-59. 
Bowker, R. 2010, Egypt and the Politics of Change in the Arab Middle East, Cheltenham: Edward Elgar.

'Drew, Robinson and Co' 1929, Albany Advertiser, 20 August, p. 1, viewed June 2013, http://nla.gov.au/nla.news-article70198079

Dumas, A., et al. 2004, Matisse, His Art and His Textiles: The Fabric of Dreams, London: Royal Academy.

'Easter fair at the Yarra Glen Presbyterian church' 1897, Evelyn Observer, 30 April, p. 2, viewed June 2013, http://nla.gov.au/nla.news-article60696224.

‘Egyptian cloth’ 1930, Sydney Morning Herald, 31 January, p. 5.

'Egyptian cloth' 1944, Mercury (Hobart), 4 October, p. 16, viewed June 2013, http://nla.gov.au/nla.news-article26037918.

'Egyptian patch-work' 1910-1912, Every Woman's Encyclopedia, viewed June 2013, http://chestofbooks.com/food/household/Woman-Encyclopaedia-3/ Bayeux-Tapestry-Part-2.html\#.Uc5VKvnvh8E.

'Egyptian tent work' 1926, Daily News (Perth), 16 November, p. 7, viewed June 2013, http://nla.gov.au/nla.news-article82035867.

Feeney, J. 1986, 'The tentmakers of Cairo', Saudi Aramco World, June, viewed June 2013, http://www.saudiaramcoworld.com/issue/198606/tentmakers. of.cairo.htm.

Garrett, C. 1982, Islamic Art from Michigan Collections, East Lansing: Kresge Art Gallery.

Gagnon, B. 2002, 'Egyptian appliques: Tourism and tradition', M.A. thesis, University of Rhode Island.

- - 2003, 'Egyptian applique', Uncoverings: The Research Papers of the American Quilt Study Group, vol. 24, pp. 131-62.

Gillow, J. 2013, Textiles of the Islamic World, London: Thames and Hudson.

Goodwin, G. 1988, 'Gardens of the dead in Ottoman times', Muqarnas, vol. 5, pp. 61-69, viewed June 2013, http://www.jstor.org/stable/1523110.

Gostelow, M. 1982, Embroidery: Traditional Designs, Techniques and Patterns from all over the World, London: Marshall Cavendish.

'La Donna' 1954, 'Eastern scenes and waving palms', Advocate, 24 September, p. 14, viewed June 2013, http://nla.gov.au/nla.news-article69865459.

'Martha' 1939, 'Right ideas for your bed-sitter', Catholic Press, 17 August, p. 4, viewed June 2013 http://nla.gov.au/nla.news-article106366545. 
'Matrimonial' 1899, Bendigo Advertiser, 20 December, p. 2, viewed June 2013, http://nla.gov.au/nla.news-article89472657.

Murray, K. 2010, 'Outsourcing the hand: An analysis of craft-design collaborations across the global divide', craft + design enquiry, no. 2, viewed June 2013, http://press.anu.edu.au//apps/bookworm/view/craft+++design+enquiry\%3 b+issue+2,+2010/10201/ch04.html.

'Myer Emporium' 1930/1931, Advertiser (Adelaide), 22 August, p. 13; 26 June, p. 14, viewed June 2013.

'Near and far' 1923, Sydney Morning Herald, 18 July, p. 9, viewed June 2013, http://nla.gov.au/nla.news-article16081364.

Paine, S. 1990, Embroidered Textiles: Traditional Patterns from Five Continents, London: Thames and Hudson.

Perrot, G. \& Chipiez, C. 1883, A History of Art in Ancient Egypt, W. Armstrong (trans.).

Ramadan, A. 2010, 'Tradition vs Modernism in the Street of the Tentmakers', EgyptIndependent, 21 August, viewed June 2013, http://www. egyptindependent.com/news/tradition-vsmodernism-street-tentmakers.

Ricucci, T. 2006, 'Real appliqued tent', Lazygalquilting, (blog), 14 June, viewed June 2013, http://lazygalquilting.blogspot.com.au/2006/06/real-appliquedtent.html.

Rinehart, M.R. 1926, Nomad's Land, New York: Doran.

Sachs, S. 2000, 'Cairo journal - A tentmaker's wish: Make the bazaar splendid!', New York Times, 18 August, viewed June 2013, http://www.nytimes. com/2000/08/18/world/cairo-journal-a-tentmaker-s-wish-make-the-bazaarsplendid.html.

Sladen, D. 1908, Egypt and the English: Showing British Public Opinion in Egypt upon the Egyptian Question: With Chapters on Success of the Sudan and the Delights of Travel in Egypt and the Sudan, London: Hurst and Blackett.

- - 1911a, Queer Things about Egypt, Philadelphia: J.B. Lippincott.

- - 1911b, Oriental Cairo: The City of the Arabian Nights, Philadelphia: J.B. Lippincott.

'Social world - motor ambulances' 1917, Adelaide Mail, 17 February, p. 8, viewed June 2013, http://nla.gov.au/nla.news-article59430686.

Stone, C. 2010, 'Movable palaces', Saudi Aramco World, April, viewed June 2013, http://www.saudiaramcoworld.com/issue/201004/movable.palaces.htm. 
'The Lord Mayor's Ball - beauty and magnificence in an Egyptian setting' 1926, Register (Adelaide), 14 May, p. 12, viewed June 2013, http://nla.gov.au/nla. news-article56573133.

'The Sydney City Mission' 1900, Sydney Morning Herald, 31 October, p. 5, viewed June 2013, http://nla.gov.au/nla.news-article14355462.

'Uses of linen crash' 1930, Sydney Morning Herald, 31 January, p. 5, viewed June 2013, http://nla.gov.au/nla.news-article16622062.

'Very special auction of high class furnishings' 1932, Townsville Daily Bulletin, 21 April, p. 10, viewed June 2013, http://nla.gov.au/nla.news-article61358863.

Wroe, D. 2008, 'Not far from Cairo's madding crowds', Sydney Morning Herald, 1 March, viewed June 2013, http://www.smh.com.au/news/africa/not-farfrom-cairos-madding-crowds/2008/02/28/1203788502558.html. 
This text taken from craft + design enquiry issue 6, 2014, Craft.Material. Memory, Edited by Anne Brennan and Patsy Hely, published 2014 by ANU Press, The Australian National University,

Canberra, Australia. 